\title{
Current trends in literary production in Esperanto*
}

\author{
Jukka Pietiläinen \\ University of Tampere
}

\begin{abstract}
We can divide Esperanto literature into four historical periods. The first (1887-1920) was characterised by the important role of translations. The second period (1921-1945) was marked by the development of poetry and also, to some extent, of prose and drama. The third period (1946-1974), while beset with difficulties, continued the development started in the second period and made some new innovations, especially in poetry. The fourth period (since 1975) has so far been a period in which the novel and experimental poetry have flourished. Unlike the earlier periods, the fourth period is no longer dominated by a small group of authors and influential literary magazines: Esperanto literature is now more diverse and fragmented, leaving space for different schools and linguistic styles.
\end{abstract}

Keywords: Esperanto, literature, history of literature, Esperanto culture, literacy traditions, developments of Esperanto language

\section{The definition of periods in Esperanto literature}

Traditionally Esperanto literature has been divided into three periods: the first before the First World War, the second between the world wars and the third after the Second World War. This division was first formulated by William Auld in the preface to the first edition of his poetry anthology in Esperanto (Auld 1958:11). It has been used also by two rather comprehensive presentations of Esperanto literature in English, by Janton (1993) and Nuessel (2000). ${ }^{1}$ The traditional division into periods is based on events outside the world of Esperanto, although the wars had a certain impact on the Esperanto movement and literature. The First World War clearly closes the first period of Esperanto literature, not only because of the war but also because of the demise of four 
distinguished authors: Esperanto's founder Ludwik Zamenhof died in 1917, the poet and translator Antoni Grabowski died in 1921, the prose translator Kazimierz Bein (known by his pseudonym Kabe) left the Esperanto movement in 1911, and the poet Vasili Devyatnin wrote his main works between 1906 and 1911 (Kralj 1960:21, Kökény \& Bleier 1933:108).

The Second World War had a less abrupt effect, mainly because the changes discernible after the war really started earlier, with the rise of totalitarian regimes in countries in which Esperanto was most popular (totalitarianism, though of a different kind, continued after the war in Eastern and Central Europe). At the same time, there are marked differences in the literature of the 1920s and 1930s and that of the 1950s and 1960s, both qualitatively and quantitatively. In the 1950s and early 1960s fewer books were published in Esperanto per year than in the 1920s and early 1930s. Only in 1963 did the number rise above 150 per year (Esperanto 6/1987:110-111). But there was qualitative progress, especially in poetry, with the appearance of modernism in the 1950s. ${ }^{2}$

According to Carlevaro the division into three periods is unscientific but usable. Although differences between periods are easily visible in poetry, they are "only very dubious as far as prose (mainly short stories) is concerned, and nonexistent concerning novels and drama" (Lapenna, Lins \& Carlevaro 1974:117). Moreover, during the first period translation was the most important element in Esperanto literature, while in retrospect original works resembled curiosities of literary history rather than artistic creations (Kralj 1960:35).

The First World War was followed by an energetic flowering of original poetry, displaying both artistic and linguistic accomplishment (Kralj 1960:39), but the interwar period was also a period of the first artistically significant novels. It is considered a period of maturation of Esperanto literature (Nuessel 2000:74). One of the most important literary events of the era was the publication of a "guidebook" for writing poetry in Esperanto, Parnasa gvidlibro (Guidebook to Parnassus) in 1932. The work of Hungarian poet and translator Kálmán Kalocsay and French poet Gaston Waringhien, Parnasa gvidlibro defined the ideal model of poetic style in Esperanto.

After the Second World War the work of many pre-war authors continued, but external conditions changed. The political persecution of Esperantists had started in the 1930s both in Germany and in the Soviet Union and persisted in countries under Soviet occupation or influence (Lins 1988). Indeed the Cold War and the division of Europe into two groups of states had an immense impact on Esperanto culture. Literatura Mondo (Literary World), the outstanding literary review of the 1920s and 1930s, was re-launched in Hungary in 1947, but was definitively closed in 1949 . 
On the other hand, new literary journals were launched, particularly Nica Literatura Revuo (Literary Review of Nice) in France (1955-1962) and Norda Prismo (Northern Prism) in Sweden (1955-1975). One of the epoch-making literary works was Kvaropo (Quartet), by four poets of the Scottish school, in 1952. Only in the 1960s did the detente in international relations and the strengthening of state-funded Esperanto associations in Central and Eastern Europe change the situation. During this period Esperanto-literature became more international than ever before. Important authors appeared in Japan, China, South Africa, Brazil and other countries of Latin America. However, this third period is to a great extent a continuation of the second period. Thus, William Auld (1979) analysed prose in terms of continuous development from 1930 to 1977 and emphasised that the Scottish school followed the model of Parnasa gvidlibro, the founding literary model of the 1930s.

In the afterword to the second edition of his anthology of Esperanto poetry (1984) Auld suggested a division of the development of Esperanto poetry into four periods: primitive romanticism before 1917, mature romanticism from 1918 to 1931, Parnassism (on the basis of Parnasa gvidlibro) up to 1956 (the date of Auld's La infana raso, The Infant Race), and Post-Parnassism since 1956. ${ }^{3}$ Actually, in line with Auld's periodisation, one could divide Esperanto poetry up to the middle of the 1970s into a mere two periods, the dividing line being the influence of the Budapest school (around the literary magazine Literatura Mondo) and the publishing of Parnasa gvidlibro in 1932.

\section{The beginning of the fourth period}

The quantity of Esperanto literature in the past two or three decades exceeds all the other decades put together, and qualitatively one can speak of a completely new era. This new period came into being not because of an important event outside the Esperanto community, but because of developments within the literature itself.

If, analogously with earlier changes, we looked for an occasion outside the Esperanto community to mark the start of the fourth period, the most natural would be the year 1989, when the collapse of the Eastern European regimes had far-reaching effects on the Esperanto movement and culture, including literature. The state-funded Esperanto associations in the region lost their official role and funding, but Esperantists gained more freedom of movement and less ideological control. The emergence of alternative ways of making international 
contacts, along with the collapse of the economy, brought a sharp fall in membership figures in official Esperanto associations.

But no such change in the development of Esperanto literature is discernible. Publishing continued, and the demise of traditional "official" publishers, such as the Hungarian Esperanto Association (HEA), was quickly compensated by the launch of new independent ones, like Impeto and Sezonoj in Russia and Pro Esperanto in Austria.

In fact, if we observe original literature in Esperanto during recent decades it is possible to put the beginning of the fourth period at the beginning of the 1970s, with the appearance of new literary magazines and the closure of some others and an immense growth in the number of original novels. Purely quantitatively, a marked increase took place as early as 1963, when the number of books published in Esperanto grew from 131 to 201, thereafter falling only occasionally (in the early 1990s) below $170 .{ }^{4}$ During the thirty years from 1933 to 1963 the number of books published in Esperanto never reached that level. ${ }^{5}$

The launch of the journal Literatura Foiro in 1970 could be defined as a starting point for the fourth period, along with the closure of Norda Prismo in 1975, but the role of individual literary magazines has lessened in recent years. Publisher Juan Régulo Pérez, who made an enormous contribution to Esperanto literature, both original and translated, during the third period, ceased publishing activity at the beginning of the 1970s after producing almost one hundred volumes over twenty-two years under the Stafeto imprint. It has been suggested that Esperanto poetry fell into crisis after Stafeto disappeared and left a gap in Esperanto culture (Trujillo Casañas 1997, Benczik 1987:62, de'Giorgi 1987:230).

In 1975 the Raymond Schwartz Prize was announced (Esperanto, December 1975, 218). The prize was to be awarded in 1980 for the best new novel in Esperanto and was intended as a stimulus to would-be novelists (Janton 1993:105). Ten manuscripts by nine authors were received and the prize itself was won by Éva Tófalvi and Oldřich Kníchal for Kiuj semas plorante... (Those Who Sow and Weep, not actually published until 1984: see Kamaĉo 1990:8-9). The prize had the desired effect: the 1980s was the best period for original Esperanto novels, at least in terms of numbers.

A crisis in the most important literary competition in Esperanto, the annual Belartaj Konkursoj (Fine Arts Competitions) of Universal Esperanto-Association (UEA), also testifies to a change of direction: "From 1969 to 1975 not a single first prize for prose was given" and "in 1973 and 1974 (...) the first prize was not given in any field" (Johansson 2000:203). Possibly the crisis lay less in 
literary production than in the jury, which was made up of Gaston Waringhien, Roger Bernard and Emilija Lapenna, all associated with an earlier period. In the mid-1970s changes in the jury and a new generation of participants made the prizes flourish again. As of 1976 the Belartaj Konkursoj were limited to original works (before that, prizes were given also for translation) and also new fields, such as essays and photography, and later songs and children's literature, were added (Johansson 2000:202). Perhaps not accidentally, the change of era coincided with a change in the leadership of the Universal Esperanto Association: Ivo Lapenna, for several decades the leading figure in the Association, was replaced by a new leadership with a new approach to the world and to Esperanto literature.

We have noted that the fourth period is distinguishable by the strong role of novels. Between 1907 and 1999 approximately 130 original novels were published in Esperanto, more than half of them after 1975, and half after 1980. We might even define the beginning of the fourth period by the publication of Lorjak's novel Neologisme (With Neologisms) in 1975, the pseudonymous work of Jacques-Louis Mahé. Neologisme is a modest book; with its 88 pages it hardly attains the approximate minimum extent of 100 pages for a novel, ${ }^{6}$ but it was the first novel to appear since 1963, and such a long period without original novels had not occurred before. From then on, however, at least one original novel has been published in Esperanto every year. On the other hand, during the 1960s several collections of short stories appeared, and they paved the way for the later flood of novels (often by the same authors). ${ }^{7}$ In 1976 a second novel by Lorjak was published, and also a novel by Johán Valano (pseudonym of Swiss author Claude Piron), $\hat{C} u$ vi kuiras cine? (Do You Cook Chinese?), one of the first crime novels in Esperanto.

A look at the number of novels during different decades clearly indicates their increasing importance - though the 1930s were also an important period for novels and produced a record broken only in the 1980s. The highest number of novels was published in 1987 and 1988, which marked the 100th anniversary of Esperanto.

In the second half of the 1980s twenty-two original novels were published, nine of them by Central and Eastern European publishing houses (actually by only one publishing house: the Hungarian Esperanto Association), but during the first half of the 1990s only eight original novels appeared, two or three of them in Central and Eastern Europe. Some Western European publishing houses also experienced problems: both the Flemish Esperanto Association and Edistudio, in Italy, published fewer original novels in the 1990s. As we have 


\begin{tabular}{lr}
\hline Novels published originally in Esperanto & \\
\hline $1900-1909$ & 2 \\
$1910-1919$ & 5 \\
$1920-1929$ & 11 \\
$1930-1939$ & 20 \\
$1940-1949$ & 4 \\
$1950-1959$ & 4 \\
$1960-1969$ & 3 \\
$1970-1979$ & 11 \\
$1980-1989$ & 42 \\
$1990-1999$ & 25 \\
$2000-2004$ & 16 \\
\hline
\end{tabular}

(For comprehensive lists, see http://esperanto.net/literaturo/roman/index.html and http://www.rano. org/romanoj.html).

noted, the disappearance of HEA as a publisher was compensated by several Russian publishers, and in Western Europe new publishers also emerged, but this took time. Among literary magazines the collapse of the Eastern European regimes hit Hungara Vivo (Hungarian Life), which ceased publication in 1991, but fortunately the Russian La Ondo de Esperanto (Wave of Esperanto) partly assumed its role. ${ }^{8}$

In the late 1990s the situation normalised again, with seventeen novels in Esperanto. The present decade (2000-2009), may be the second or third most productive: during the first five years sixteen original novels have appeared.

In poetry the fourth period is not as outstanding as in prose. For example, of the volumes of poetry in the recommended basic reading list for an Esperantist prepared by the Scottish author William Auld, only the second edition of Esperanta antologio (Esperanto Anthology 1984) was published after 1975. The recommended reading list, which was first published in Auld's La fenomeno Esperanto (The Phenomenon of Esperanto, 1988), provided a "Basic Reading List of Original Esperanto Literature." Auld updated the list in 1997, when it was published in several Esperanto journals and later also in the Internet. Even though a revised version of the reading list (Auld 1997) includes seven new poetry books, six of them published during the fourth period, still only every fourth poetry book dates from the fourth period, while $37 \%$ of prose works belong to this category. 


\section{Elements of the fourth period}

In the fourth period the volume of original literature in Esperanto has increased significantly: there are more books with more pages, in part because of the growth in the number of novels. During the 1960s about 150 volumes of fiction were published, of which less than one third (42) were originally written in Esperanto; but in the 1990s about seven hundred were published, of which 260 (40\%) were original. During the 1960s (actually 1961-69) about four hundred books (fiction and non-fiction) were produced, of which one hundred were originally written in Esperanto. During the 1990s about 2,100 books were published, of which the majority were original. The average number of pages has increased from 90 to $120 .{ }^{9}$ Even if these figures might include some flaws (data for the 1960s may be less complete and data for the 1990s also includes books about Esperanto in other languages), they tell us something about the quantitative growth of Esperanto literature and the increasing role of original literature.

According to another source (Boulton 1989:96), in the 87 years from the beginning of Esperanto to the year 1974 the number of prose books or booklets (both original and translated) was at least 1,529, while 590 prose books or booklets appeared between 1974 and 1987. It has been calculated that during the 1990s approximately 900 prose works were published. On the basis of these figures approximately one half of all prose works have been published during the fourth period.

Among the most productive novelists of the fourth period are the Hungarian István Nemere (fourteen novels), the Swiss Johán Valano (pseudonym of Claude Piron, seven) and the French Lorjak (Jacques-Louis Mahé, seven). In addition to them, several authors have written two or three novels each, and the total number of novel-writers reaching print is approximately forty. In fact, during the fourth period several novels written earlier were finally published. For example, Ivan Shiryaev's Sen titolo (Without Title), apparently the first novel written in Esperanto, was composed around 1900 but published only in $1995 .{ }^{10}$

The novels of the fourth period represent a large spectrum of styles and genres. Especially noteworthy is the abundance of crime novels: of 44 novels published between 1965 and 1988 (LePuil 1988:11) one fourth (11) are crime novels, one fourth (11) social and adventure novels and one sixth (7) autobiographical and psychological. Before 1975 only two novels in Esperanto could be classified as crime novels while the majority of novels were science fiction, love stories, adventure stories, or social and philosophical in nature. 
Several novels are set in Esperanto circles, alluring readers because of their plot and setting. They include Oni ne pafas en Jamburg (There Is No Shooting in Yamburg) and Dek tagoj de kapitano Postnikov (The Ten Days of Captain Postnikov), both by Russian author Mikaelo Bronŝtejn, Murdo en Esperantujo (Murder in Esperanto-Country) by Daniel Moirand, of France, Kiuj semas plorante... by the Czechoslovakian couple Éva Tófalvi and Oldřich Kníchal, Ombro sur interna pejzaĝo (Shadow on an Inner Landscape) by Croatian novelist Spomenka Štimec, and La Manto (The Mantis), a roman à clef by a pseudonymous Paula Mährti.

Also popular are novels set in the realm of international politics beyond Esperanto society, though even these have often absorbed something of the Esperanto community in their explicitly humanistic tone. Examples are works by Australian novelist Trevor Steele, British author John Francis and several novels by Nemere (see above; other novels by Nemere are clearly adventure novels aimed at entertainment). To the genre of entertainment belong two love stories by the British author Manjo Austin.

While novels are the most characteristic phenomenon of the fourth period, we should not neglect other branches of literature. For poetry the mid-1970s could not be regarded as a major breaking point; a significant shift in style had happened earlier, perhaps with Auld's La infana raso (The Infant Race, 1956) - although the British Esperanto poet Kris Long has argued as late as the 1980s that true modernist poets are rare in Esperanto, as opposed to poets influenced by romantic ideas (Ragnarsson 1989:109). It is clear that poetry in Esperanto is no longer guided by the rules set by Kalocsay and Waringhien in Parnasa gvidlibro. That paradigm has long since passed and the new era needs no guidebooks. The most influential schools of poetry in the fourth period were formed only in the 1990s. Of these schools, the so-called Iberian school has common linguistic and stylistic traits, but the Moscow school can be defined only geographically and on the basis of a local Esperanto literary group.

A special genre of poetry, the lyrics for Esperanto music, particularly rock music, represents a clear break in comparison with the earlier period. Musical culture in Esperanto was almost non-existent before 1975: the comprehensive presentation of the Esperanto movement and community Esperanto en perspektivo (Esperanto in Perspective; Lapenna, Lins \& Carlevaro 1974), gives music almost no attention (although Esperanto choruses have a long history). But as of the beginning of the 1980s popular music has become an essential part of contemporary Esperanto culture. The first rock groups were established in the 1980s and an association of rock groups was founded in 1988. They were 
preceded by numbers of folk singers, whose first recordings were published at the end of the 1970s. The popularization of cassettes made the publishing of Esperanto music much easier, and since 1988 CDs have also been published (see, for example, http://www.vinilkosmo.com/?prs=listen).

Linguistically the fourth period has brought conflict with ideas prevailing during earlier periods. The battle over the nature of the Esperanto language, evident since the early days of the language, between "those who favored the relatively schematic nature of Esperanto (the application of systems and rules to maximize expressivity)" and "those who favored greater naturalism (the achievement of expressivity through the importation of terms and concepts, their semantic fields already represented in existing ethnic languages)" (Tonkin 2000a:27), has been partly responsible for the division of literary production into different schools, for example in the strict-constructionist so-called Analytical School led by Richard Schulz (Rikardo Sulĉo). The battle exploded again in 1975, when the distinguished Hungarian scholar István Szerdahelyi criticized the official theory of derivation of words, generated by Kálmán Kalocsay and Gaston Waringhien and sanctioned by the Academy of Esperanto (Martinelli and others 1994). This criticism was echoed by Claude Piron in his book La bona lingvo (The Good Language) in 1989. It is not so much that new paradigms emerged, as that literature entered an increasingly non-paradigmatic era.

Indeed, beside the quantitative growth of Esperanto literature the most important element of the fourth period is its fragmentation. There are hardly any leading literature magazines in the style of Literatura Mondo or Norda Prismo anymore. Literatura Foiro (Literary Fair) has become an organ of a small ideological and literary tendency, Fonto (Spring), and recently La Ondo de Esperanto, have failed to gain a large readership, and the literary role of the major magazine Esperanto has decreased (for example, there is no longer a special annual literary issue). Fragmentation is also visible in the role of dictionaries and grammars. Plena ilustrita vortaro (Waringhien 1970, succeeded by Duc Goninaz 2002) has been criticized because of its naturalistic tendency. Plena analiza gramatiko de Esperanto (Complete Analytical Grammar of Esperanto: Kalocsay and Waringhien 1980) has been outdated and partly replaced by other grammars which are based on different linguistic ideas, such as the Internet-based Plena manlibro de Esperanta gramatiko (Complete Handbook of Esperanto Grammar) by Swedish scholar and Esperanto rock musician Bertil Wennergren.

The rise of spoken Esperanto, resulting from easier travel, greater use of telephones, and the emergence of Esperanto music, is having an increasing 
impact on Esperanto literature, while written Esperanto has been undergoing changes in style since the late 1990s because of e-mail and internet discussions. The experimental use of the language by some authors has had little influence on the wider public and the literary use of the language "seems less far removed linguistically from ordinary usage than it once was" (Tonkin 2000a:32). However, in the works of several authors a lack of contact with the Esperanto speech community can still be seen: the Australian novelist Ronald Cecil Gates refers to imposto sur aldonita valoro (value-added tax, VAT) although in spoken Esperanto the tax is known as aldonvalora imposto, while the translator of Pippi Longstocking, according to one reviewer, has probably never actually encountered Esperanto-speaking children.

\section{Why write in Esperanto?}

Czech author Karolo Pić describes dilemmas of Esperanto authors in his novel La Litomiŝla tombejo: "And you are struggling... with the internal sense of futility, with the fact that the results of your work remain unused, that you are writing only for your own drawer, for nothing, for nobody" (Pić 1981:200). Decades earlier Kálmán Kalocsay described himself in a poem En amara horo (In a bitter hour) as "a poet without a people".

But this is no longer so: Esperanto authors have an audience, though small. Esperanto has become a fully functional language with, proportionally, wide publishing activity, and it is no longer possible to read all the books published in Esperanto (Boulton 2004). The audience of an Esperanto author is worldwide if very thin. The typical number of published copies of a given title is less than a thousand and the diffusion of literature to the audience might take several years. An Esperanto author who might be known worldwide among Esperantists might be completely unknown in his/her own locality. Moreover, the most unique feature of Esperanto literature has remained: it is a literature largely written in a language other than the mother tongue of the author (though there are some authors, like Brazilian Sara Larbar, who are native speakers of Esperanto).

Even if the audience is small, the links between audience and author are often close. An Esperanto author has a good chance of meeting the greater part of his/her audience. The audience regularly following literary events in Esperanto might be as low as five hundred (Benczik 1980:137), but the literature is also very international: a novel by an Australian author might be published in 
Austria or Brazil or a novel by a French author published in Finland and read in several dozen countries.

Occasionally an author can gain publicity through Esperanto which might be impossible in some other language. In 1985, for example, Nemere was able to publish a novel in Esperanto entitled Alta akvo (High Water), on the effects of a dam project. The topic was on the agenda in Hungary at that time, because Czechoslovakia was planning a dam which would harm the living conditions of the Hungarian minority. Quite possibly he could not have published the work in Hungarian.

An early personal account of the Holocaust period, Maskerado cirkaŭ la morto (Masquerade around Death), was published in Esperanto in 1965 by Tivadar Soros, the father of George Soros, the financier. The book, which describes how the Soros family survived in wartime Hungary, would have had little appeal for English-language publishers at the time (and Soros did not have a good command of English), and there was no possibility of its being published in Hungarian, at least not in communist Hungary itself. The book was published in English translation only in 2000 (for the history of this book see Tonkin 2000b). Other more recent Esperanto authors offer similar examples. Anna Löwenstein published her historical novel Stona urbo (The Stone City 1999) both in English and in Esperanto. In English its fate was similar to many first works of new authors, but in Esperanto it became widely known (with three printings so far).

In many ways the development of Esperanto literature resembles the development of literatures in small European languages, in which translations and poetry were important initially, and only afterwards original prose grew to dominance. In small literatures, especially in Eastern Europe, both the writing and reading of literature was considered an act of patriotism. A similar sense of commitment informed the early development of Esperanto literature, and this pioneering spirit has continued at least until recently (Benczik 1980:136). In Esperanto several thousand readers can be reached worldwide; for many authors, in increasing numbers, the effort to write and publish in Esperanto is worth making.

\section{Notes}

* The article is based on an earlier article published in Esperanto in Fonto 24/1 (2004). The author thanks Humphrey Tonkin for valuable comments and the University of Tampere Centre for Advanced Study for the research appointment during which this article was written. 
1. For a comprehensive review of proposals for periodisation in Esperanto literature by various authors see de Kock (1987:308).

2. On the history of Esperanto poetry see Tonkin 1993.

3. On the impact of La infana raso see Benczik 1980.

4. The number of published books is based on two statistics: the number of books in the Hector Hodler Library in Rotterdam (Blaine 1987:110-111) and the number of books appearing on the market during a given year according to the lists of new books in the journal Esperanto between 1987 and 2004.

5. Georgo Kamaĉ (2003) has suggested starting the fourth period with the year 1971 because of the influence of Plena ilustrita vortaro (PIV, the Complete Illustrated Dictionary, Waringhien 1970), at the time the largest dictionary in Esperanto. The publication of PIV certainly had an important role in the development of Esperanto literature, but, given the slowness of the book market in Esperanto, the impact of PIV would not be instant and in any case its effect on the language and literature was important but not epoch-making.

6. This definition was applied to Esperanto novels by Auld (1981) and by Buller in his list of original Esperanto novels published at the end of István Nemere's novel Pigre pasas la nokto (The Night Passes Lazily) in 1992.

7. Using a different classification, Johansson records one or two novels between 1963 and 1975, but according to Auld and Buller they likely fall into categories of longer short stories or autobiographical works.

8. The fall in the number of original novels published in the 1990s suggests that the collapse of the Central and Eastern European political regimes had a negative impact on Esperanto literature in general (or at least Esperanto book production), even if the decline was far less drastic than the decline in membership figures. In its list of recent publications, the journal Esperanto recorded 215 books in 1989; in 1990 the number dropped to 183, and in 1993 to only 136. But by 1995 it was back again to over 200 and has not fallen below 200 since then.

9. For the 1960s, see Lapenna, Lins \& Carlevaro 1974:47; for the 1990s, see Korjenkov 2003.

10. This is not a new phenomenon: Vojaĝo al Kazohinio, Journey to Kazohinio, by Hungarian author Sandor Szathmári, was composed in the 1930s but published only in 1958 (Paris: SAT).

\section{References}

Auld, William. 1979. Enkonduko en la originalan literaturon de Esperanto. Saarbrücken: Artur E. Iltis.

Auld, William.1981. Vereco, distro, stilo: Romanoj en Esperanto. Saarbrücken: Artur E. Iltis. 
Auld, William. 1988. La fenomeno Esperanto. Rotterdam: Universala Esperanto-Asocio. Auld, William. 1997. Pri legolistoj. La Brita Esperantisto 93/4:135. [Reprinted in Esperanto 91/1 (1998):16. Complete list at http://www.rano.org/legolisto.html and with commentaries in English at http://donh.best.vwh.net/Esperanto/EBook/app04.html.]

Auld, William, ed. 1958. Esperanta Antologio, Poemoj 1887-1957. La Laguna: J. Régulo.

Auld, William, ed. 1984. Esperanta Antologio. Poemoj 1887-1981. 2nd ed. Rotterdam: Universala Esperanto-Asocio.

Benczik, Vilmos. 1980. Studoj pri la Esperanta literaturo. Takasago, Japan: La Kritikanto.

Benczik, Vilmos. 1987. La rolo de la eldonejo Stafeto en la konservado de la kontinueco de la Esperanta literaturo. In Serta Gratulatoria in Honorem Juan Régulo, II, Esperantismo. La Laguna: Universidad de la Laguna. 61-64.

Blaine, Roĝero. 1987. Tra densa polvnubo briletas la celo. Esperanto 80/6:110-111.

Boulton, Marjorie. 1989. Cent jaroj de Esperanta prozo. In Klaus Perko, ed. Memorlibro pri la Internacia jubilea esperanto-konferenco. Rødovre, Denmark: Perspektivo. 95-101.

Boulton, Marjorie. 2004. La unika situacio de esperanta verkisto. Revised version of paper presented at the British Esperanto Congress, Felixstowe, 3 May 2004. http://www.everk. org.

Buller, Osmo. 1990. Hamburgo en beletra vivo. In Serta Gratulatoria in honorem Juan Régulo, IV Arqueología y arte. Miscelánea. La Laguna: Universidad de la Laguna. 677-682.

Carlevaro, Tazio.1974. Originala beletro. In Lapenna, Lins \& Carlevaro 1974:122-189.

de'Giorgi, Aldo. 1987. La rolo de eldonistoj en la Esperanto-movado kaj la krizo de la esperanta poezio post Stafeto. In Serta Gratulatoria in Honorem Juan Régulo, II, Esperantismo. La Laguna: Universidad de la Laguna. 223-234.

Duc Goninaz, Michel, ed. 2002. La nova plena ilustrita vortaro de Esperanto. Paris: Sennacieca Asocio Tutmonda.

Esperanto. Journal of Universal Esperanto Association. 1987-2004.

Janton, Pierre. 1993. Esperanto: Language, Literature, and Community. Ed. Humphrey Tonkin; trans. Humphrey Tonkin, Jane Edwards \& Karen Johnson-Weiner. Albany: State University of New York Press.

Johansson, Sten. 2000. Belartaj Konkursoj de UEA 1950-1999. Esperanto 93/12:202-205. [Available also at http://esperanto.net/literaturo/bk/bkeseo.html.]

Johansson, Sten. Originalaj romanoj en Esperanto. http://esperanto.net/literaturo/roman/ index.html.

Kalocsay, Kálmán \& Gaston Waringhien. 1932. Kiel fariĝi poeto aŭ Parnasa gvidlibro. Budapest: Literatura Mondo.

Kalocsay, Kálmán \& Gaston Waringhien. 1980. Plena analiza gramatiko de Esperanto. 4th ed. Rotterdam: Universala Esperanto-Asocio.

Kamaĉo, Georgo. 1990. Originalaj romanoj en Esperanto: panoramo kaj perspektivoj. Fonto 10/2:5-11. [Available also at http://esperanto.net/literaturo/roman/libr/romaneseo. html.]

Kamaĉo, Georgo. 2003. Ne ciio verda estas smeralda. Esperanto 96/2:38-39.

Kock, Edwin de. 1987. La Regula Stafeto al la originala esperanta poezio. In Serta Gratulatoria in Honorem Juan Régulo, II, Esperantismo. La Laguna: Universidad de la Laguna. 301-313.

Kökény, L. \& V. Bleier, eds. Enciklopedio de Esperanto. 1933. Budapest: Literatura Mondo. 
Korjenkov, Aleksander. 2003. Eldonado en Esperantujo: Jaro 2002. La Ondo de Esperanto 2(100):21.

Kralj, Drago. 1960. Kvar prelegoj pri esperanta literaturo. Ljubljana: Slovenia EsperantoLigo.

Lapenna, Ivo, Ulrich Lins \& Tazio Carlevaro. 1974. Esperanto en perspektivo. Rotterdam: Universala Esperanto-Asocio.

LePuil, Ĵak. 1988. La romano en Esperanto ekde la jaroj 1968. Fonto 8/11:9-18.

Lins, Ulrich. 1988. La danĝera lingvo: Studo pri la persekutoj kontraŭ Esperanto. Gerlingen, Germany: Bleicher. [Published also in German (Die gefährliche Sprache, Die Verfolgung der Esperantisten unter Hitler und Stalin, 1988), Italian (La lingua pericolosa, 1990), Russian (Opasnyi jazyk, 1999), Lithuanian (2005) and in shorter form in Japanese (1975).]

Martinelli, Perla Ari. 1994. La 25 jaroj de Literatura Foiro. Dulingva ekspozicio en Budapeŝto, 10-16 septembro 1994. Esperanta PEN-centro kaj Pro Helvetia.

Nuessel, Frank. 2000. The Esperanto Language. New York, Ottawa, Toronto: Legas.

Pić, Karolo. 1981. La Litomiŝla tombejo. Saarbrücken: Artur E. Iltis.

Piron, Claude. 1989. La bona lingvo. Vienna: Pro Esperanto; Budapest: Hungara EsperantoAsocio.

Ragnarsson, Baldur. 1989. Cent jaroj de poezio en Esperanto. In Klaus Perko, ed. Memorlibro pri la Internacia jubilea esperanto-konferenco. Rødovre, Denmark: Perspektivo. $102-111$.

Soros, Tivadar. 2000. Maskerado. Dancing around Death in Nazi Hungary. Ed. and trans. Humphrey Tonkin. Edinburgh: Canongate. [First published in Esperanto in 1965.]

Tonkin, Humphrey. 1993. Esperanto Poetry. In Alex Preminger \& T.V.F. Brogan, ed. New Princeton Encyclopedia of Poetry and Poetics. Princeton, NJ: Princeton University Press. 381-382.

Tonkin, Humphrey. 2000a. The Role of Literary Language in Esperanto. Interface. Journal of Applied Linguistics 15/1:11-35.

Tonkin, Humphrey. 2000b. Editor's Afterword. In Soros, 2000: 211-226.

Trujillo Casañas, Leandro. 1997. La Sociedad Esperantista de Tenerife cumple cuarenta años. El Día, Santa Cruz de Tenerife. http://www.terra.es/personal2/letruca/webdoc12.htm.

Waringhien, Gaston, ed. 1970. Plena ilustrita vortaro de Esperanto. Paris: Sennacieca Asocio Tutmonda.

Wennergren, Bertilo. Plena manlibro de Esperanta gramatiko. http://bertilow.com/pmeg/.

\section{Tiivistelmä}

\section{Esperantokirjallisuuden viimeaikaisia kehityssuuntia}

Esperantokirjallisuus voidaan jakaa neljään kauteen. Ensimmäisen kauden (1887-1920) aikana käännöksillä oli tärkeä rooli. Toiselle kaudelle (1921-1945) oli ominaista runouden sekä jossain määrin myös proosan ja draaman kehittyminen. Kolmatta kautta (1946-1974) leimasivat vaikeudet, mutta samalla toisella kaudella alkanut kehitys jatkui ja uusia suuntia avattiin etenkin runoudessa. Neljäs kausi (vuodesta 1975 alkaen) on tähän mennessä ollut 
romaanien ja kokeilevan runouden kukoistuskausi. Aikaisemmista kausista poiketen neljännellä kaudella ei ole kyse muutaman kirjailijan ja kirjallisuuslehden hallitsevasta roolista: Esperantokirjallisuus on pirstaleisempi ja moninaisempi, jolloin tilaa jää eri koulukunnille ja kielellisille tyyleille. Arviolta noin puolet alun perin esperantoksi kirjoitetuista proosateoksista ja kaksi kolmasosaa romaaneista on ilmestynyt neljännellä kaudella.

\section{Resumo}

\section{Nuntempaj tendencoj en literatura produktado en Esperanto}

Oni povas dividi la esperantan literaturon en kvar periodojn. Dum la unua periodo (18871920) la rolo de tradukoj estis aparte grava. La duan periodon (1921-1945) karakterizas evoluo de poezio kaj parte de prozo kaj dramo. La tria periodo (1946-1974) portis al Esperanto kaj ĝia literaturo malfacilajojn, sed ĝi signifis ankaŭ daŭrigon de la evoluo komencinta dum la dua periodo kaj novajn eltrovojn aparte en poezio. La kvara periodo (ekde 1975) signifis ĝis nun floradon de romanoj kaj de eksperimenta poezio. Malsame de pli fruaj periodoj dum la kvara periodo ne temas pri superrego de kelkaj verkistoj kaj literaturaj revuoj: la esperanta literaturo estas pli diversa kaj pli fragmentita kaj pro tio restas spaco por diversaj skoloj kaj lingvaj stiloj. Proksimume duono el originalaj esperantaj prozajoj kaj du trionoj el originalaj romanoj aperis dum la kvara periodo.

\section{Author's address}

Jukka Pietiläinen

33014 University of Tampere

Finland

jukka.pietilainen@uta.fi

\section{About the author}

Jukka Pietiläinen holds a Ph.D. from the University of Tampere and is a researcher at the University of Tampere Centre for Advanced Study (2004-2005). His research has focused on media and journalism in Russia, international news, Russian society, and Esperanto literature. 
Copyright of Language Problems \& Language Planning is the property of John Benjamins Publishing Co.. The copyright in an individual article may be maintained by the author in certain cases. Content may not be copied or emailed to multiple sites or posted to a listserv without the copyright holder's express written permission. However, users may print, download, or email articles for individual use. 